\title{
Evaluation and Speciation of Heavy Metals Contamination of Selected Artisanal Mining Sites in Mangu Local Government Area of Plateau State, Nigeria
}

\author{
Nanven D. Nimyel and Elizabeth S. Chundusu
}

\section{ABSTRACT}

\begin{abstract}
Artisanal (illegal) mining has been reported to have environmental and health effects on the surrounding communities due to heavy metals pollution. The determination of total heavy metal concentration does not reflect the toxicity and bioavailability of the metals. Toxicity and bioavailability of the metals can be achieved by determining the form in which the metal exist in the environment (speciation). This present work evaluated the heavy metals' \{cadmium (Cd), copper (Cu), manganese (Mn), lead ( $\mathrm{Pb})$, zinc ( $\mathrm{Zn})$ \&nickel (Ni)\} contamination and the form in which they exist at some mining sites in Mangu LGC, Plateau state, Nigeria. Aqua regia $\left(\left(\mathrm{HCl}+\mathrm{HNO}_{3}, 3: 1 \mathrm{v} / \mathrm{v}\right)\right.$ was used for total metal concentration while sequential extraction method was used to orderly determine the speciation of the heavy metals. The level of the heavy metals in the digested solutions were determined using Buck Scientific model 210VGP Atomic Absorption Spectrophotometer (AAS). The results divulged that the concentrations of the heavy metals were within the FEPA and WHO recommended permissible limit except $\mathrm{Cd}$ and $\mathrm{Ni}$. The values of the metals at Mangu Halle mining site followed the sequence: $\mathrm{Mn}>\mathrm{Zn}>\mathrm{Ni}>\mathrm{Pb}>\mathrm{Cu}>\mathrm{Cd}$ whereas the sequence at Alogwom was $\mathrm{Mn}>\mathrm{Zn}>\mathrm{Pb}>\mathrm{Ni}>\mathrm{Cu}>\mathrm{Cd}$. The results of the speciation indicated that all metals were bound to the five fractions with the residual fraction dominating except $\mathrm{Cd}$ which was bound mostly to the soluble and exchangeable fractions. It could be concluded that the presence of these heavy metals in the mobile fractions, indicate that they could be easily released to the environment from soil. Thus, they are also likely to cause toxicity in the environment. Proper monitoring of the mining activities in the communities was recommended.
\end{abstract}

Keywords: Artisanal, contamination, Heavy Metals, Mining, Speciation.
Published Online: October 22, 2021

ISSN : 2684-4478

DOI : $10.24018 /$ ejchem.2021.2.4.78

\section{N. D. Nimyel*}

Department of Science, School of Science and Technology, Plateau State Polytechnic, Barkin Ladi, Nigeria.

(e-mail: nimyelnanven@yahoo.com) E. S. Chundusu

Department of Science, School of Science and Technology, Plateau State Polytechnic, Barkin Ladi.

*Corresponding Author

\section{INTRODUCTION}

Mining has contributed greatly to the economy of many low- and middle-income countries that are rich in non-fuel mineral resources [1]. However, when not properly monitor, indiscriminate and unorganized mining can mar the benefits because of its potential for environmental and health impacts [2], [3]. Today, there are widespread artisanal (illegal) mining taking place in Jos South, Barkin Ladi, Riyom, Jos North and Mangu Local Government Areas of Plateau State. Most of the mining activities are undertaken by artisanal miners which are seen as surface or artisanal mining. These are done with little or no technology adaptation to handle the damages of the mining activities [4]. The mining activities have led to mining ponds, dams, and alluvial deposits, which have been abandoned due to the unprofessional handling of the mining [5]. These have immediate and long term environmental and health implications to the communities' concern [6], [7].
Currently, most of the mining communities have taken to dry season irrigation farming of vegetables using the abandoned mining ponds/dams as their source of water. Also, mining heaps and sands/tailings are used for construction purposes [8]. Most of the mining activities are undertaken by artisanal miners which are seen as surface or artisanal mining. These are done with little or no technology adaptation to handle the damages of the mining activities [9]. Mustafa and Ezeamaka [9] also posited that increasing impact witness over the years was as a result of the fact that most of the miners undertake the activities in mining areas not known to the government and its agencies responsible for the regulation of mining activities. They further said, this in turn makes it difficult for the government to monitor their operations in order to inflict environmental regulations on them. All these have health implications to the society as heavy metals would be introduced into the environment. Many researchers have expressed fears that high and excessive amount of heavy 
metals in the soil may eventually contaminate both human and animal food chain [10], [11]. This is because unlike some of the organic pollutants, metals have the tendency to remain in the environment for a long time. They cannot be biodegradable and their residence time in the soil can be thousands of years [12]. The determination of total heavy metal concentrations can only be used to assess heavy metal pollution but cannot be used to assess the mobility and bioavailability of the heavy metals [13], [14]. To determine or assess the toxicity, mobility, reactivity, and bioavailability of heavy metals in the environment, speciation can be an efficient tool to environmentalists [14], [16]. Therefore, heavy metal speciation in soils plays an important role in environmental risk assessment of soil heavy metal pollution. In this assessment, only the soil labile fraction is taken into account because this fraction is often called the bioavailable fraction [11], [15]. According to Huang et al. [17], "the concentration of heavy metal's solution in the soil, their form of association with other soluble species and the ability of the soil to release them from the solid-phase to the soil solution determine the mobility, bioavailability and the potential toxicity of these metals in the soil." They further stated that the knowledge of the chemical forms in which those metals are found reveals their behaviour within the environment. The simplest method to identify the speciation of heavy metals in the environment is sequential extraction. In this method, the components that are loosely held in the soil are extracted first, followed by those that are more tightly bonded [12]. The sequential extraction method consists of five different fractions as proposed by Tessier et al. [18] and modified by other researchers. Therefore, the main objectives of the present study are to evaluate the heavy metals contamination of selected artisanal mining sites in Mangu LGA of Plateau State and determine the speciation of the heavy metals in the environment.

\section{MATERIALS AND METHODS}

\section{A. Description of Study Area}

Mangu is a Local Government Area in Plateau State, Nigeria. Its headquarters is in the town of Mangu at $9^{\circ} 31^{\prime} 00^{\prime \prime} \mathrm{N} 9^{\circ} 06^{\prime} 00^{\prime \prime} \mathrm{E}$. It has an area of $1,653 \mathrm{~km}^{2}$ and a population of 294931 at the 2006 census. Mechanized mining has stopped in Mangu but artisanal (illegal) mining is still going at the time of this research leaving behind so many abandoned mining ponds, dams, alluvial deposits, and mining wells scattered all over.

\section{B. Sample Collection}

Samples for this study were collected majorly through qualitative techniques during the fieldwork that took place in the study area between September and December 2019. Soil, samples were collected randomly from Mangu Halle and Alogwom mining sites in Mangu LGA. The soil samples from five sites in Mangu Halle and four soil samples from Alogwom were collected for this study. The soil samples were air-dried, crushed, and sieved to $2 \mathrm{~mm}$, then stored prior to analysis of heavy metals.

\section{Analysis of Heavy Metals in Soil}

Three grams ( $3.0 \mathrm{~g})$ of the sieved soil sample was weight in a Pyrex conical flask and digested with $25 \mathrm{ml}$ of aqua regia $\left(\mathrm{HCl}+\mathrm{HNO}_{3}, 3: 1 \mathrm{v} / \mathrm{v}\right)$ at $120{ }^{\circ} \mathrm{C}$ on a water bath in a fume cupboard. The digested sample was cooled and filtered into a $100 \mathrm{ml}$ volumetric flask and made up to the mark with distilled/deionised water [13], [18]. This process was repeated. The concentration of the heavy metals in the digested soil sample solutions were determined using Buck Scientific model 210VGP Atomic Absorption Spectrophotometer (AAS) at wavelengths and slits specific to each metal. The metals analysed were lead $(\mathrm{Pb})$, copper $(\mathrm{Cu})$, nickel $(\mathrm{Ni})$, zinc $(\mathrm{Zn})$, cadmium $(\mathrm{Cd})$ and manganese $(\mathrm{Mn})$.

\section{Sequential Extraction of Metals}

The method reported by Asagba et al. [19] was used for the sequential extraction of the heavy metals with slight modification.

\section{1) Soluble fraction [F1]}

The soluble fraction was extracted with $10 \mathrm{~mL}$ of distilled/deionized water for 16 hours on a mechanical shaker. After each extraction process, liquid-solid separation was affected by centrifuging the mixture at $1,500 \mathrm{rpm}$ for 15 minutes. The supernatant was decanted into a plastic sample bottle for metal analysis while the residue was kept for step II.

\section{2) Exchangeable fractions [F2]}

The exchangeable fraction was extracted using $1 \mathrm{M} \mathrm{BeCl}_{2}$, (instead of $\mathrm{MgCl}_{2}$ ), $\mathrm{pH}$, in stoppered polyethylene bottles at room temperature [13]. To the residue from $\mathrm{F} 1,10 \mathrm{~mL}$ of $1 \mathrm{M}$ $\mathrm{BeCl}_{2}$ was added, and this was agitated for 10 hours on a mechanical shaker. The supernatant was decanted into a plastic sample bottle for metal analysis while the residue was kept for step III.

\section{3) Carbonate fraction [F3]}

To the residue from $\mathrm{F} 2,8 \mathrm{~mL}$ of $1 \mathrm{M} \mathrm{NaOAc}$ was added, and this was adjusted to $\mathrm{pH} 5.0$ with acetic acid (HOAc). The mixture was agitated for 5 hours

\section{4) $\mathrm{Fe} / \mathrm{Mn}$ bound fraction [F4]}

This fraction was extracted from the residue of [F3] with a mixture of hydroxylamine hydrochloride $\left(\mathrm{NH}_{2} \mathrm{OH}\right.$. $\left.\mathrm{HCl}\right)$ and $0.2 \mathrm{M}$ trioxonitrate $(\mathrm{V})$ acid $\left(\mathrm{HNO}_{3}\right)$ and agitated at room temperature for 1 hour [13].

\section{5) The residual fractions (bound to Silicates) [F5]}

The residual fraction was extracted with $25 \mathrm{ml}$ of aqua regia $\left(\mathrm{HCl}+\mathrm{HNO}_{3}, 3: 1 \mathrm{v} / \mathrm{v}\right)$ at $120{ }^{\circ} \mathrm{C}$ on water bath in fume cupboard. Metal levels in each fraction were determined using the calibrated Buck Scientific model VGP 210.

\section{RESUlTS AND DISCUSSION}

\section{A. Concentration of Heavy Metals at the Mining Sites}

The results of the analyses of soil samples from Mangu Halle and Alogwom mining sites are presented in Tables I \& II. From Table I, the concentration of Mn ranged from 40.03$94.85 \mathrm{mg} / \mathrm{kg}$ with an average of $60.07 \mathrm{mg} / \mathrm{kg}$ whereas $\mathrm{Cu}$ ranged from 17.48 to $25.85 \mathrm{mg} / \mathrm{kg}$. Ni ranged from 52.17 to $84.64 \mathrm{mg} / \mathrm{kg}$, Cd ranged from 1.85-6.75 mg/kg, $\mathrm{Pb}$ ranged 
from 15.4-45.4 $\mathrm{mg} / \mathrm{kg}$ whereas $\mathrm{Zn}$ ranged from 109.91$157.34 \mathrm{mg} / \mathrm{kg}$. Similarly, from Table II, the concentrations of the heavy metals at Alogwom, Mn ranged from 135.11$359.11 \mathrm{mg} / \mathrm{kg}$ with an average of $237.70 \mathrm{mg} / \mathrm{kg}$ whereas $\mathrm{Cu}$ ranged from $11.56-12.96 \mathrm{mg} / \mathrm{kg}$ with an average of $12.18 . \mathrm{Ni}$ ranged from $20.56-22.43 \mathrm{mg} / \mathrm{kg}$, Cd ranged from $0.44-$ $0.56 \mathrm{mg} / \mathrm{kg}, \mathrm{Pb}$ ranged from $33.83-43.77 \mathrm{mg} / \mathrm{kg}$ with an average of $4.15 \mathrm{mg} / \mathrm{kg}$ whereas $\mathrm{Zn}$ ranged from 44.55 $65.23 \mathrm{mg} / \mathrm{kg}$.

\section{1) Manganese (Mn)}

In this study as can be seen in Tables II and III, Mn had the highest value of $194.85 \mathrm{mg} / \mathrm{kg}$ at Mangu mining site and $359.11 \mathrm{mg} / \mathrm{kg}$ at Alogwom. The concentration of $\mathrm{Mn}$ in this study is similar to the report of Shibdawa et al. [20] in Dorowa Mining Areas of Barkin Ladi, Plateau State, Nigeria. The results also revealed that the concentrations of $\mathrm{Mn}$ at all the sites were within the permissible limit of $2000 \mathrm{mg} / \mathrm{kg}$ recommended by FAO/WHO, [21]. Shibdawa et al. [20] reported that manganese $(\mathrm{Mn})$ is frequently an abundant constituent of soils, but its low solubility at neutral and alkaline $\mathrm{pH}$ prevents excessive uptake by plants. He further asserted that manganese toxicity is nearly always associated with acid soils.

\section{2) Copper $(\mathrm{Cu})$}

Similarly, copper was one of the heavy metals detected in all the soil samples from the areas around the Mangu Halle and Alogwom artisanal mining sites (see Tables II and III). It has a mean concentration ranging from $17.48-25.58 \mathrm{mg} / \mathrm{kg}$ and $11.56-12.96 \mathrm{mg} / \mathrm{kg}$ at Mangu and Alogwom respectively. The concentration of $\mathrm{Cu}$ suggested that there could be anthropogenic contribution since artisanal mining is taking place in the vicinity of these areas. The results also revealed that the concentrations of $\mathrm{Cu}$ are within the permissible limit of $30 \mathrm{mg} / \mathrm{kg}$ recommended by WHO [22]. Similar results were reported by Singh et al. [23] at $1.5 \mathrm{~km}$ distance from the active mining sources and Ali et al. [24] but lower values were reported by Sanusi et al. [25]. The low values of $\mathrm{Cu}$ as postulated by other researchers, could be due to its mobility in weathering environment and its ability to adsorb onto soil constituents surfaces through ion exchange process [25], [26].

\section{3) $\mathrm{Nickel}(\mathrm{Ni})$}

The results of $\mathrm{Ni}$ as can be seen in Tables II and III, revealed that the highest value of $84.64 \mathrm{mg} / \mathrm{kg}$ was recorded at Mangu while the highest value of $22.43 \mathrm{mg} / \mathrm{kg}$ was recorded at Alogwom. The concentrations of $\mathrm{Ni}$ in this study are also similar to the report of Shibdawa et al. [20] but higher than those reported by other researchers [27], [28]. The values obtained from these studies are higher than the FAO/WHO maximum permissible level of $40 \mathrm{mg} / \mathrm{kg}$ in soil at Mangu Halle but the values are within the permissible limit at Alogwom. According to Alshaebi et al. [29] in Shibdawa et al. [20] $\mathrm{Ni}$ contaminates the soil when the concentration of $\mathrm{Ni}$ is higher than $40 \mathrm{mg} / \mathrm{kg}$. Hence, these results show that the soil is contaminated by $\mathrm{Ni}$ at Mangu Halle. This could be due to the source of mining. They further asserted that the highest concentration of $\mathrm{Ni}$ is usually found at the top layer of the soil that is rich in organic matter or with relatively high content of clay.

\section{4) $\operatorname{Lead}(\mathrm{Pb})$}

Similar, $\mathrm{Pb}$ was also found in all the soil samples investigated. It had mean concentrations ranging from 15.40$45.40 \mathrm{mg} / \mathrm{kg}$ at Mangu and 33.83-43. $75 \mathrm{mg} / \mathrm{kg}$ at Alogwom. The results of $\mathrm{Pb}$ revealed that the concentrations are within the permissible limit of $85 \mathrm{mg} / \mathrm{kg}$ recommended by WHO [22] and FAO/WHO maximum permissible level of $100 \mathrm{mg} / \mathrm{kg}$ in soil. The values of $\mathrm{Pb}$ in this study are lower compared to those reported by other researchers [25], [30], [31] but conforms to the findings of other researchers [20], [24]. The low levels of $\mathrm{Pb}$ in the soil as observed from the results could be due to its mobility in weathering environment and the ability to adsorb onto soil constituent surfaces through ion exchange process [25], [26].

5) Zinc $(Z n)$

Zn was also detected in all the soil samples investigated (Tables II \&III). The mean concentrations of $\mathrm{Zn}$ ranged from 109.16-157.34 mg/kg at Mangu Halle and 144.55$165.23 \mathrm{mg} / \mathrm{kg}$ at Alogwom mining area. Mangu had the highest values of $157.34 \mathrm{mg} / \mathrm{kg}$ at site E while Alogwom had the highest value of 165.23 at site A. The results revealed that the concentrations of $\mathrm{Zn}$ were above the permissible limit of $50 \mathrm{mg} / \mathrm{kg}$ recommended by WHO [22]. The high values of $\mathrm{Zn}$ in the soils suggest that there could be anthropogenic contribution. Since local mining have taken place around these areas which no doubt may have contributed to high concentration of $\mathrm{Zn}$ metal in the soils. The concentrations of $\mathrm{Zn}$ in this study are however lower than the values reported by Sanusi et al. [25] but higher than the values reported by Ali et al. [24].

\section{6) Cadmium $(C d)$}

Likewise, the results showed that $\mathrm{Cd}$ was detected in all the soil samples investigated with an average concentration of $3.37 \mathrm{mg} / \mathrm{kg}$ and $0.51 \mathrm{mg} / \mathrm{kg}$ at Mangu and Alogwom respectively. This is contrary to what was reported by Ali et al. [24] where Cd was detected only in one sample. The concentrations of $\mathrm{Cd}$ in this study were higher than those reported by Ali et al. [24] and Sudan and Ako et al. [32]. The results also revealed that the concentration of $\mathrm{Cd}$ varies with sites in the study area with the highest concentration obtained at site $\mathrm{C}(6.75 \pm 0.16 \mathrm{mg} / \mathrm{kg})$ for Mangu mining area and highest at $\mathrm{A}(0.56 \pm 0.04 \mathrm{mg} / \mathrm{kg})$ for Alogwom mining area. From these results, it could be seen that all the values were above the WHO [22] recommended maximum limit of cadmium in the soil $(0.35 \mathrm{mg} / \mathrm{kg})$.

Generally, the average concentrations of all the heavy metals at Mangu Halle and Alogwom mining sites were within the WHO [22] and FAO/WHO maximum permissible level except $\mathrm{Ni}$ at Mangu Halle and $\mathrm{Cd}$ which had concentrations above their maximum recommended limits. Generally, the concentrations of $\mathrm{Cd}$ at Mangu Halle were higher than the values at Alogwom village. The concentrations of the metals at mangu Halle mining site decreased in the order $\mathrm{Mn}>\mathrm{Zn}>\mathrm{Ni}>\mathrm{Pb}>\mathrm{Cu}>\mathrm{Cd}$ while the sequence at Alogwom was $\mathrm{Mn}>\mathrm{Zn}>\mathrm{Pb}>\mathrm{Ni}>\mathrm{Cu}>\mathrm{Cd}$. 
TABLE I: AVERAgE ConcENTRATION OF HEAvy METALS IN SOIL AT Mangu Halle Mining Site

\begin{tabular}{ccccccc}
\multicolumn{7}{c}{ MANGU HALLE MiNING SITE } \\
\hline Sample & \multicolumn{7}{c}{ Concentration $(\mathrm{mg} / \mathrm{kg})$} \\
\hline \multirow{2}{*}{$\mathrm{A}$} & 59.99 & 17.48 & 52.17 & 3.23 & 27.10 & 132.35 \\
& \pm 2.04 & \pm 1.06 & \pm 3.67 & \pm 0.05 & \pm 4.35 & \pm 25.33 \\
$\mathrm{~B}$ & 59.65 & 25.85 & 84.64 & 2.61 & 20.60 & 109.16 \\
& \pm 3.15 & \pm 3.26 & \pm 8.15 & \pm 0.01 & \pm 5.63 & \pm 20.18 \\
$\mathrm{C}$ & 45.81 & 23.18 & 67.02 & 6.75 & 15.40 & 154.13 \\
& \pm 5.99 & \pm 6.19 & \pm 8.01 & \pm 0.16 & \pm 3.33 & \pm 22.25 \\
$\mathrm{D}$ & 94.85 & 19.08 & 69.52 & 2.39 & 25.50 & 109.91 \\
& \pm 6.79 & \pm 4.11 & \pm 5.54 & \pm 0.14 & \pm 5.55 & \pm 16.88 \\
$\mathrm{E}$ & 40.03 & 18.55 & 80.68 & 1.85 & 45.40 & 157.34 \\
& \pm 4.44 & \pm 2.25 & \pm 7.22 & \pm 0.04 & \pm 1.58 & \pm 22.10 \\
Av. & 60.07 & 20.83 & 70.81 & 3.37 & 26.80 & 132.58 \\
& \pm 19 & \pm 3.17 & \pm 11.4 & \pm 1.75 & \pm 7.75 & \pm 20.69 \\
Control & 18.11 & 5.30 & 1.12 & 0.11 & 0.25 & 26.00 \\
& \pm 0.01 & \pm 0.01 & \pm 0.01 & \pm 0.01 & \pm 0.01 & \pm 0.44 \\
\hline
\end{tabular}

TABLE II: Average ConcENTRATION of HeAvy Metals In SoIl AT ALOGWOM MINING SiTE

\begin{tabular}{ccccccc}
\hline \multirow{2}{*}{ Sample } & \multicolumn{7}{c}{ Concentration $(\mathrm{mg} / \mathrm{kg})$} \\
\cline { 2 - 7 } & $\mathrm{Mn}$ & $\mathrm{Cu}$ & $\mathrm{Ni}$ & $\mathrm{Cd}$ & $\mathrm{Pb}$ & $\mathrm{Zn}$ \\
\hline \multirow{2}{*}{$\mathrm{A}$} & 135.11 & 12.96 & 22.43 & 0.56 & 33.83 & 165.23 \\
& \pm 22.3 & \pm 1.24 & \pm 2.33 & \pm 0.04 & \pm 0.13 & \pm 2.44 \\
$\mathrm{~B}$ & 285.34 & 11.56 & 20.66 & 0.44 & 34.32 & 156.15 \\
& \pm 55.8 & \pm 2.22 & \pm 0.15 & \pm 0.08 & \pm 1.10 & \pm 2.10 \\
$\mathrm{C}$ & 171.23 & 11.57 & 20.56 & 0.55 & 43.75 & 162.34 \\
& \pm 8.15 & \pm 1.50 & \pm 0.11 & \pm 0.12 & \pm 0.55 & \pm 2.13 \\
$\mathrm{D}$ & 359.11 & 12.64 & 20.60 & 0.49 & 35.70 & 144.55 \\
& \pm 24.1 & \pm 3.44 & \pm 0.04 & \pm 0.01 & \pm 0.22 & \pm 5.86 \\
\multirow{2}{*}{ Av. } & 237.70 & 12.18 & 21.06 & 0.51 & 36.90 & 157.07 \\
& \pm 89.3 & \pm 0.63 & \pm 0.79 & \pm 0.05 & \pm 0.39 & \pm 7.94 \\
\multirow{2}{*}{ Control } & 18.11 & 5.30 & 1.12 & 0.11 & 0.25 & 26.0 \\
& \pm 0.01 & \pm 0.01 & \pm 0.01 & \pm 0.01 & \pm 0.01 & \pm 0.44 \\
\hline
\end{tabular}

\section{Speciation of Heavy Metals at the Mining Sites}

The speciation study was conducted to ascertain the forms of the heavy metals in the soil. The concentrations of the five chemical fractions for six heavy metals $(\mathrm{Cd}, \mathrm{Zn}, \mathrm{Cu}, \mathrm{Ni}, \mathrm{Pb}$ $\& \mathrm{Mn}$ ) are presented in Tables III \& V while the percentages of the metals in the different fractions are presented in Tables IV \& VI. From these tables, the results showed that cadmium (Cd) was associated with all the fractions with the exchangeable fraction having $32.12 \%$ and $35.11 \%$ at Mangu and Alogwom respectively (Tables III \& IV). The predominance of $\mathrm{Cd}$ in the mobile fractions (soluble and exchangeable fractions) has been reported [13], [33]. The high percentage of $\mathrm{Cd}$ in the mobile fractions $(62.78 \%)$ poses serious potential threat to the ecosystem and enhance potential bioavailability [14], [34]. The association of $\mathrm{Cd}$ follows the order: exchangeable fractions > soluble fraction $>$ carbonate fraction > Fe/Mn bound fraction > residual fraction at Mangu Halle while at Alogwom, the distribution follows the pattern: exchangeable fractions > soluble fraction $>$ residual fraction > Fe/Mn bound fraction > carbonate fraction. Zinc on the order hand was predominantly bound to the non-mobile fractions (residual fraction \& Fe/Mn bound fraction) accounting for $69.27 \%$ at Mangu Halle and $68.75 \%$ at Alogwom. This is similar to the reports of other researchers [13]. Hussain [34] and Ochiagha et al. [12] reported that heavy metals that are mostly bound to the residual fraction are not easily bioavailable to plants in the environment. The distribution of $\mathrm{Zn}$ on the order hand at Mangu Halle and Alogwom follows the pattern: residual fraction > Fe/Mn bound fraction $>$ carbonate fraction $>$ soluble fraction $>$ exchangeable fraction. Similarly, copper $(\mathrm{Cu})$ was found in all the fractions at the two mining sites with the residual fraction having the highest percent. This is in agreement with Ochiagha et al. [12] but in contrast with the report of Shivakumar et al. [35] where $\mathrm{Cu}$ was found in only two fractions. The association of $\mathrm{Cu}$ in the fractions at the two mining sites follow the order: residual fraction $>$ carbonate fraction $>$ exchangeable fraction $>\mathrm{Fe} / \mathrm{Mn}$ bound fraction $>$ soluble fraction.

The results also revealed that nickel (Ni) at Mangu Halle was found predominantly in the residual fraction with $50.00 \%$ while at Alogwom it was found predominantly with the $\mathrm{Fe} / \mathrm{Mn}$ bound fraction with $71.78 \%$. This agrees with Omuku et al. in Ochiagha et al. [12]. The high association of $\mathrm{Ni}$ in the non-mobile fraction may be attributed to the alkaline stabilization process of the soil [13]. The association of nickel (Ni) follows the pattern: residual fraction > exchangeable fraction > Fe/Mn bound fraction > carbonate fraction > soluble fraction while at Alogwom the pattern was slightly different: $\mathrm{Fe} / \mathrm{Mn}$ bound fraction > residual fraction > exchangeable fraction $>$ carbonate fraction $>$ soluble fraction.

TABLE III: HEAVY METAL SPECIATION IN SOIL OBTAIN FROM MANGU HALLE MINING SITE

\begin{tabular}{cccccc}
\hline Heavy & \multicolumn{5}{c}{ Concentration $(\mathrm{mg} / \mathrm{kg})$} \\
\cline { 2 - 6 } Metal & $\mathrm{F} 1$ & $\mathrm{~F} 2$ & $\mathrm{~F} 3$ & $\mathrm{~F} 4$ & $\mathrm{~F} 5$ \\
\hline \multirow{2}{*}{$\mathrm{Cd}$} & 1.26 & 1.32 & 0.96 & 0.23 & 0.34 \\
& \pm 0.02 & \pm 0.04 & \pm 0.12 & \pm 0.06 & \pm 0.01 \\
$\mathrm{Zn}$ & 10.14 & 6.44 & 12.17 & 19.46 & 45.32 \\
& \pm 0.04 & \pm 0.15 & \pm 0.01 & \pm 0.05 & \pm 0.01 \\
$\mathrm{Cu}$ & 0.25 & 0.67 & 0.75 & 0.54 & 2.67 \\
& \pm 0.04 & \pm 2.11 & \pm 0.22 & \pm 0.12 & \pm 0.12 \\
$\mathrm{Ni}$ & 0.34 & 0.45 & 0.38 & 0.43 & 1.66 \\
& \pm 0.11 & \pm 0.03 & \pm 0.02 & \pm 0.22 & \pm 0.05 \\
$\mathrm{~Pb}$ & 0.07 & 0.48 & 0.28 & 0.45 & 1.60 \\
& \pm 0.08 & \pm 0.04 & \pm 0.13 & \pm 0.09 & \pm 0.11 \\
$\mathrm{Mn}$ & 27.32 & 4.24 & 3.29 & 10.18 & 122.35 \\
& \pm 1.25 & \pm 0.01 & \pm 0.07 & \pm 0.01 & \pm 3.42 \\
\hline
\end{tabular}

KEY: F1= Soluble fraction; F2 =Exchangeable fraction; F3 =Carbonate fraction; F4 =Fe/Mn bound fraction; F5 Residual fraction.

TABle IV: Percent of Heavy Metals Speciation at Mangu Halle MINING SITE

\begin{tabular}{cccccc}
\hline Heavy & \multicolumn{5}{c}{ Concentration $(\mathrm{mg} / \mathrm{kg})$} \\
\cline { 2 - 6 } Metal & $\mathrm{F} 1$ & $\mathrm{~F} 2$ & $\mathrm{~F} 3$ & $\mathrm{~F} 4$ & $\mathrm{~F} 5$ \\
\hline $\mathrm{Cd}$ & 30.66 & 32.12 & 23.36 & 5.60 & 8.27 \\
$\mathrm{Zn}$ & 10.84 & 6.89 & 13.01 & 20.81 & 48.46 \\
$\mathrm{Cu}$ & 5.12 & 13.73 & 15.37 & 11.07 & 54.71 \\
$\mathrm{Ni}$ & 10.63 & 14.06 & 11.88 & 13.44 & 50.00 \\
$\mathrm{~Pb}$ & 2.38 & 16.33 & 9.52 & 15.31 & 54.42 \\
$\mathrm{Mn}$ & 16.32 & 2.53 & 0.17 & 6.08 & 73.10 \\
\hline
\end{tabular}

F1 = Soluble fraction; F2 = Exchangeable fraction; F3 = Carbonate fraction; $\mathrm{F} 4=\mathrm{Fe} / \mathrm{Mn}$ bound fraction; F5 = Residual fraction.

TABLE V: HeAvy Metal SPECIATION IN SOIL ObTAin FROM Alogwom

\begin{tabular}{cccccc}
\multicolumn{5}{c}{ MiNING SITE } \\
\hline Heavy & \multicolumn{5}{c}{ Concentration $(\mathrm{mg} / \mathrm{kg})$} \\
\cline { 2 - 6 } Metal & $\mathrm{F} 1$ & $\mathrm{~F} 2$ & $\mathrm{~F} 3$ & $\mathrm{~F} 4$ & $\mathrm{~F} 5$ \\
\hline \multirow{2}{*}{$\mathrm{Cd}$} & 0.28 & 0.33 & 0.06 & 0.13 & 0.14 \\
& \pm 0.02 & \pm 0.04 & \pm 0.12 & \pm 0.06 & \pm 0.01 \\
$\mathrm{Zn}$ & 10.33 & 1.44 & 2.14 & 10.46 & 20.14 \\
& \pm 0.04 & \pm 0.15 & \pm 0.01 & \pm 0.05 & \pm 0.01 \\
$\mathrm{Cu}$ & 2.25 & 1.38 & 1.75 & 12.54 & 15.67 \\
& \pm 0.04 & \pm 2.11 & \pm 0.22 & \pm 0.12 & \pm 0.12 \\
$\mathrm{Ni}$ & 0.34 & 0.45 & 0.38 & 6.60 & 1.43 \\
& \pm 0.11 & \pm 0.03 & \pm 0.02 & \pm 0.22 & \pm 0.05 \\
$\mathrm{~Pb}$ & 1.37 & 0.49 & 0.78 & 10.45 & 20.60 \\
& \pm 0.08 & \pm 0.04 & \pm 0.13 & \pm 0.09 & \pm 0.11 \\
$\mathrm{Mn}$ & 1.18 & 11.24 & 10.29 & 27.32 & 124.35 \\
& \pm 0.01 & \pm 0.01 & \pm 0.07 & \pm 1.25 & \pm 3.42 \\
\hline
\end{tabular}

F1= Soluble fraction; F2 = Exchangeable fraction; F3 = Carbonate fraction; $\mathrm{F} 4=\mathrm{Fe} / \mathrm{Mn}$ bound fraction; F5 = Residual fraction. 
TABLE VI: Percent of HeAvy Metals Speciation AT Alogwom Mining SiTE

\begin{tabular}{cccccc}
\hline \multirow{5}{*}{ Heavy Metal } & \multicolumn{5}{c}{ Concentration $(\mathrm{mg} / \mathrm{kg})$} \\
\cline { 2 - 6 } & $\mathrm{F} 1$ & $\mathrm{~F} 2$ & $\mathrm{~F} 3$ & $\mathrm{~F} 4$ & $\mathrm{~F} 5$ \\
\hline $\mathrm{Cd}$ & 29.78 & 35.11 & 6.38 & 13.83 & 14.89 \\
$\mathrm{Zn}$ & 23.21 & 3.23 & 4.81 & 23.50 & 45.25 \\
$\mathrm{Cu}$ & 6.70 & 4.11 & 5.21 & 37.33 & 46.65 \\
$\mathrm{Ni}$ & 3.70 & 4.89 & 4.13 & 71.74 & 15.54 \\
$\mathrm{~Pb}$ & 3.45 & 1.23 & 1.97 & 26.33 & 51.90 \\
$\mathrm{Mn}$ & 0.67 & 6.45 & 5.90 & 15.67 & 71.31 \\
\hline
\end{tabular}

F1= Soluble fraction; F2 = Exchangeable fraction; F3 = Carbonate fraction; $\mathrm{F} 4=\mathrm{Fe} / \mathrm{Mn}$ bound fraction; F5 = Residual fraction.

Lead (Pb) was also associated predominantly in the residual fraction with $54.42 \%$ at Mangu Halle and $51.90 \%$ at Alogwom. This suggests that the leaching of the metal to the environment is not possible from the studied samples sites [13]. The results of $\mathrm{Pb}$ in this study is not in agreement with the report of Odoh et al. [36]. They reported the predominance of $\mathrm{Pb}$ in the carbonate fraction. The order of availability of $\mathrm{Cu}$ in different fractions also follows the pattern: residual fraction > exchangeable fraction $>\mathrm{Fe} / \mathrm{Mn}$ bound fraction $>$ carbonate fraction $>$ soluble fraction at Mangu Halle while the pattern at Alogwom was residual fraction > Fe/Mn bound fraction > exchangeable fraction > carbonate fraction $>$ soluble fraction. Similarly, manganese (Mn) was associated predominantly in the residual fraction with $73.10 \%$ at Mangu Halle while at Alogwom it was $71.31 \%$. These findings could be linked to the preferential incorporation of Mn into silicate lattice [13]. The association of manganese $(\mathrm{Mn})$ follows the pattern residual fraction > soluble fraction > Fe/Mn bound fraction > exchangeable fraction > carbonate fraction at Mangu Halle while the pattern is slightly different: residual fraction $>\mathrm{Fe} / \mathrm{Mn}$ bound fraction $>$ exchangeable fraction > carbonate fraction > soluble fraction. Liang et al. [37] posited that heavy metals mostly bound to organics are more available than heavy metals in the residual fraction. Metals present in the residual fraction are a measure of the degree of environmental pollution. They also stated that the higher the metals present in this fraction, the lower the degree of pollution.

Generally, the results of the speciation studies indicated that all the metals were found in the five fractions. However, they were mostly bound to the residual fraction except $\mathrm{Cd}$ which was bound mostly to the soluble and exchangeable fractions. The presence of these heavy metals in the mobile fraction (exchangeable, bound to carbonates and oxide fractions), indicates that they could be easily be bioaccumulated by plants from soil. They are also likely to cause toxicity in the environment.

\section{CONCLUSION}

From this study, it could be concluded that the mining sites were polluted with the metals $\mathrm{Cd}, \mathrm{Mn}, \mathrm{Cu}, \mathrm{Ni}, \mathrm{Zn}$ and $\mathrm{Pb}$ and the average concentrations of all the heavy metals at mining sites were within the FEPA and FAO/WHO maximum permissible level except $\mathrm{Ni}$ and $\mathrm{Cd}$ which had concentrations above their maximum recommended limits. It could also be concluded that the existence of these heavy metals in the mobile phase indicates that they could be easily released to the environment from soil. Therefore, they are likely to cause toxicity in the environment because, toxicity of heavy metals does not depend on its total concentration but depends on different forms in which metals are present.

\section{ACKNOWLEDGEMENT}

The authors are very grateful to Tertiary Education Trust Fund (TETFund) for sponsoring the research. The authors are grateful to the Laboratory Technologist and Management of the Plateau State Polytechnic, Barkin Ladi, Nigeria.

\section{COMPETING INTERESTS}

Even though this research was sponsored by Tertiary Education Trust Fund (TETfund) in Nigeria. Authors do declare that no competing interests exist.

\section{REFERENCES}

[1] M. Ericsson, and O. Olof Löf, "Mining's contribution to national economies between 1996 and 2016," Mineral Economics, 2019, vol. 32, pp. 223-250.

[2] Z. O. Opafunso, "Overview of artisanal and small scale mining of gold operations in Nigeria. Lecture at Federal University of Technology, Akure, Ondo State, Nigeria, 2011.

[3] Y. M. Ahmed, and E. D. Oruonye, "Socioeconomic impact of artisanal and small scale mining on the Mambilla Plateau of Taraba State, Nigeria," World Journal of Social Science Research, vol. 3, no. 1, pp. 1-12, 2016.

[4] I. A. Mustafa, and C. K. Ezeamaka, "Spatial location of artisanal mining activities in Niger State and its implication to the environment," International Journal of Engineering Applied Sciences and Technology, vol. 5, no.1, pp. 711-719, 2020.

[5] D. D. Davou, and I.B. Odeyemi, "Environmental impacts of mining on the Jos Plateau, Nigeria," Environmental and Health Impacts of Mining in Africa (Special Session under the Auspices of IGCP/SIDA Projects 594 and 606), January 8-14, 2013-08-22 Millennium Hall, Addis Ababa, Ethiopia.

[6] I. N. Aigbedion, and S. E. Iyayi, "Environmental effect of mineral exploitation in Nigeria," International Journal of Physical Sciences, vol. 2, no.2, pp. 033-038, 2016.

[7] O. Abdulakeem, and M. Raheem, "Environmental and health impact of mining in Abara and Tungar Community of Anka Local Governement Area of Zamfara State,Nigeria," Environmental and Health Impacts of Mining in Africa (Special Session under the Auspices of IGCP/SIDA Projects 594 and 606), January 8-14, 2013-08-22 Millennium Hall, Addis Ababa, Ethiopia.

[8] J. S. Ndace, and M. H. Danladi, "Impacts of derived tin mining activities on landuse/landcover in Bukuru, Plateau State, Nigeria," Journal of Sustainable Development, 2013, vol. 5, no. 5, pp. 1-15.

[9] I. A. Mustafa, and C. K. Ezeamaka, "Spatial location of artisanal mining activities in Niger State and its implication to the environment," International Journal of Engineering Applied Sciences and Technology, 2020, vol. 5, no.1 pp. 711-719.

[10] C. M. Iwegbue, "Metal fractionation in soil profiles at automobile mechanic waste dumps," Waste Management Research, 2007, vol. 25, pp. 1-9.

[11] J. Singh, and A. S. Kalamdhad, "Chemical Speciation of Heavy Metals in Compost and Compost Amended Soil - A Review," International Journal of Environmental Engineering Research, 2013, vol. 2, no. 2, pp. 27-37.

[12] K. E. Ochiagha, P. C. Okoye, and N. C. Eboagu, "Chemical speciation and potential mobility of heavy metals in the soils of Onitsha South Local Government Area Anambra Nigeria," American Journal of Applied Chemistry, 2020, vol. 8 no. 3, pp. 74-81. doi: 10.11648/j.ajac.20200803.12.

[13] D. N. Nimyel, J. N. Egila and Y. N. Lohdip, "Heavy Metal Speciation in Some Selected Farms Treated with Urban Solid Wasted, in Jos South, Plateau State, Nigeria," International Research Journal of Pure \& Applied Chemistry, 2015, vol. 5, no.4, pp. 342-351.

[14] Z. Xu, Y. Huanhuan, and C. Zhaojie, "Migration and speciation of heavy metal in salinized mine tailings affected by iron mining," Water Science Technol, vol. 76, no. 7, pp. 1867-1874. doi: https://doi.org/10.2166/wst.2017.369. 
[15] Y. A. Yobouet, K. Adouby, A. Trokourey, and B. Yao, "Cadmium, copper, lead and zinc speciation in contaminated soils," International Journal of Engineering Science and Technology, 2010, vol. 2, no. 5, pp. 802-812.

[16] R. Larios, R.F. Martinez and I. Rucandio, "Comparison of three sequential extraction procedures for fractionation of arsenic from highly polluted mining sediments," Analytical and Bioanalytical Chemistry, vol. 402, no. 9 pp. 2909-21. DOI:10.1007/s00216-0125730-3.

[17] S. H. Huang, Q. Li, Y. Yang, C. Y. Yuan, K. Ouyang, B. Wang, and S. Wan, "Accumulation characteristics and chemical speciation of $\mathrm{Cd}, \mathrm{Zn}$ and $\mathrm{Pb}$ in soils impacted by a $\mathrm{Pb}-\mathrm{Zn}$ Mining Area," Journal of Chemists and Chemical Engineers, 2017, vol. 66, no. 1-2, pp. 53-58.

[18] M. B. Wufem, A. Q. Ibrahim, M. H. Maina, J. G. Nangbes, and B.N. John, "Speciation of some heavy metals in soils around a cement factory in Gombe State, Nigeria," The International Journal of Engineering and Science (IJES), vol. 2, no. 9, pp. 110-115.

[19] A. A. Chokor, "The Speciation and potential bioavailability of zinc, manganese, and lead in soils of Automobile Workshops in Sapele, Nigeria," Journal of Environment and Earth Science, 2017, vol. 7, no. 3, pp. 98-106.

[20] A. M. Shibdawa, S. Lubis, H. Adamu, and S. J. Ibejekwe, "Determination of heavy metals concentration in soils used for cultivation of vegetables in Dorowa Mining Areas of Barkin Ladi, Plateau State, Nigeria," ATBU, Journal of Science, Technology \& Education (JOSTE), vol.7, no. 1, pp. 301-309.

[21] FAO/WHO (Codex Alimentarius Commission), "Food Additi-ves and Contaminants.Joint FAO/-WHO Food Standards Program, ALINORM 01/12A, pp. 1-289, 2001.

[22] WHO World Health Organisation, Guidelines for drinking water quality, World Health Organization, Geneva, 2008.

[23] R. B. Singh, A. Singh, and S. K. Choudhary, "Surface mining and heavy metal pollution of waterand soil: A case study in simlong coalfield in Sahebganj District, Jharkhand," International Journal of Applied and Natural Sciences (IJANS), vol. 4, no. 1, pp. 17-24.

[24] M. Ali, A. Elhagwa, J. Elfaki, and M. Sulieman, "Influence of the artisanal gold mining on soil contamination with heavy metals: A case study from Dar-mali locality, North of Atbara, River Nile, Sudan," Eurasian Journal of Soil Sciences, vol. 6, no. 1, pp.28-36.

[25] K. A. Sanusi, M. S. Hassan, M. A. Abbas, and A. M. Kura, "Assessment of heavy metals contamination of soil and water around abandoned $\mathrm{Pb}-\mathrm{Zn}$ mines in Yelu, Alkaleri Local Government Area of Bauchi State, Nigeria," International Research Journal of Public and Environmental Health, vol. 4, no. 5, pp. 72-77.

[26] R. A. Wuana, and F. E. Okieimen, Heavy metals in contaminated soils: a review of sources, chemistry, risks and best available strategies for remediation,"International Journal of Science \& Ecotoxicological Research, 2011, vol. 2, no.10, pp. 100-106.

[27] A. H Baghaie, and F. Aghili, "Investigation of heavy metals concentration in soil around a $\mathrm{Pb}-\mathrm{Zn}$ mine and ecological risk assessment," Environmental Health Engineering and Management Journal, 2019, vol. 6, no. 3, pp. 151-156.

[28] V. N. Daniel, E.S. Cundusu, J. A Chup, and N. D. Pius, "Variation of heavy metals in Agricultural Soil Irri-gated with Tin mining water in Heipang District of Barkin Ladi, Plateau State Nigeria," International Journal of Science and Technology, 2014, vol. 3, no. 5, pp. 225-263

[29] F. Alshaebi, W. Z. Yaacob, A. Samsudinand, E. Alsabahi, "Risk assessment at abandoned tin mine in Sungai Lembing, Pahang, Malaysia," Electronic Journal of Geotechnical Engineering, 2009, vol. 14, pp. 1-9.

[30] O. I. Nwachukwu, N. E. Ngwu, and C. Achumba, "Characterization and evaluation of selected Nigerian agricultural by- products for copper and zinc sorption," Journal of Environmental Sciences and Resource Management, 2011, pp. 103-109.

[31] C. Adah, J. Abah, S. Ubwa, and S. Ekele, "Soil Availability and Uptake of Some Heavy Metals by Three Staple Vegetables Commonly Cultivated along the South Bank of River Benue, Makurdi, Nigeria,' International Journal of Environment and Bioenergy, 2013, vol. 8, no. 2, pp. 56-67.

[32] T. A. Ako, U. S. Onoduku, S. A. Oke, I. A. Adamu, S. E. Ali, A. Mamodu, and A. T. Ibrahim, "Environmental impact of artisanal gold mining in Luku, Minna, Niger State, North Central Nigeria," Journal of Geosciences and Geomatics, 2014, vol. 2, no. 1, pp. 28-37.

[33] N. A. Obasi, E. I., Akubugwo, O. C. Ugbogu, and G. Otuchristian, "Assessment of physico-chemical properties and heavy metals bioavailability in dumpsites along Enugu-port Harcourt Expressways, South-east, Nigeria," Asian Journal of Applied Sciences, 2012, vol. 5, pp. 342-356.

[34] K. Hussain, "Determination of Heavy Metals in Two Regions from Kirkuk City Using sequential extraction," Journal of Geoscience and
Environment Protection, 2016, vol. 4, pp. 38-45. doi: 10.4236/gep.2016.42005.

[35] D. Shivakumar, S. Srikantaswamy, S. Sreenivasa, and B. M. Kiran "Speciation and geochemical behaviour of heavy metals in industrial area soil of Mysore City, India," Journal of Environmental Protection, 2012, vol. 3, pp. 1384-1392.

[36] R. Odoh, E. B. Agbaji, J. A. Kagbu, and S. A. Thomas, "Heavy metal speciation in agricultural farmland in some selected local government areas of Benue State, Nigeria," Archives of Applied Science Research, 2011, vol. 3, no. 3, pp. 560-573.

[37] S. Liang, X. Wang, Z. Li, N. Gao, and H. Sun, "Fractionation of heavy metals in contaminated soils surrounding non-ferrous metals smelting area in the North China Plain," Chemical Speciation and Bioavailability, 2014, vol. 26, no. 1, pp.59-64. 